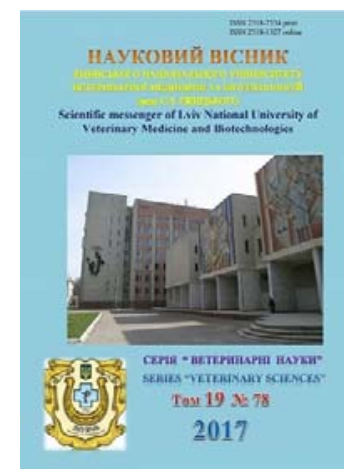

Науковий вісник Львівського національного університету ветеринарної медицини та біотехнологій імені С.З. Гжицького

Scientific Messenger of Lviv National University of Veterinary Medicine and Biotechnologies

doi:10.15421/nvlvet7806

ISSN 2518-7554 print

ISSN 2518-1327 online

$\underline{\text { http://nvlvet.com.ua/ }}$

УДК 619:611.32/.4-018:636.59

\title{
Особливості будови стравоходу та його лімфоїдної тканини горобця домового (Passer domesticus)
}

\author{
Н.В. Дишлюк \\ dushlyuk@ukr.net \\ Національний університет біоресурсів і природокористування Украӥни, \\ вул. Героїв Оборони, 15, Київ, 03041, Україна
}

\begin{abstract}
Досліджені особливості будови стравоходу та його лімфоїдної тканини горобия домового (Раsser doтеsticus). Показано, щуо стінка органу утворена добре вираженими слизовою, м'язовою і найменш розвиненою адвентиційною (серозною в каудальній частині) оболонками. Слизова оболонка формує 7-9 поздовжніх складок листоподібної і пальцеподібної форм, які спрямовані в просвіт стравоходу. Вона складається з епітелію, власної та м'язової пластинок і підслизової основи. Епітеліальний шар представлений багатомаровим плоским слабо зроговілим епітелієм $і$ краще розвинений в краніальній частині изього органу. Поблизу залозистої частини илунка він переходить в простий ичиліндричний. У власній пластиниі слизової оболонки виявляються пакети чисельних стравохідних залоз, в яких реєструється слиз. Їх вивідні протоки відкриваються на поверхню епітелію слизової оболонки. М'язова пластинка місиями переривчаста, утворена гладкою м'язовою тканиною. Підслизова основа слабо виражена, сформована, як і власна пластинка, пухкою волокнистою сполучною тканиною і кровоносними судинами.

В слизовій оболонці краніальної і каудальної частин стравоходу між залозами, їх вивідними протоками $і$ в підслизовій основі на межі з м'язовою оболонкою виявляються поодинокі скупчення дифузної лімфоїдної тканини, які представлені клітинами лімфоїдного ряду без помітних розріджень і ущільнень. Основу дифузної лімфоїдної тканини утворює ретикулярна тканина, волокна якої розтамовані щиільно, не мають певної орієнтачії і формують дрібнокоміркову сітку.

Стравохідний мигдалик, який розташований в слизовій оболониі ділянки переходу стравоходу в залозисту частину шлунка морфофункиіонально незрілий. Він утворений лише локальними скупченнями дифузної лімфоїдної тканини. Передвузлики і лімфоїдні вузлики відсутні.

М'язова оболонка стравоходу утворена гладкою м'язовою тканиною, яка формує внутрішній - ииркулярний $i$ зовнішній - поздовжній пласти. Між ними виявляються прошарки пухкої волокнистої сполучної тканини і кровоносні судини.

Адвентиційна і серозна оболонки утворені пухкою волокнистою сполучною тканиною, а серозна-ще й вкрита мезотелієм.

Ключові слова: горобець домовий, стравохід, стравохідні залози, дифузна лімфоїдна тканина, слизова оболонка, м'язова оболонка, адвентиційна (серозна) оболонка.
\end{abstract}

\section{Особенности строения пищевода и его лимфоидной ткани воробья домового (Passer domesticus)}

\author{
Н.В. Дышлюк \\ dushlyuk@ukr.net \\ Наииональный университет биоресурсов и природопользования Украины, \\ ул. Героев Обороны, 15, Киев, 03041, Украина
}

Исследованы особенности строения пищевода и его лимфоидной ткани воробья домового (Passer domesticus). Показано, что стенка органа образована хорошо выраженными слизистой, мымечной и наименее развитой адвентициальной (серозной в каудальной части) оболочками. Слизистая оболочка формирует 7-9 продольных складок листовидной и пальцевидной форм, направленных в просвет пищевода. Она состоит из эпителия, собственной и мышееной пластинок и подсли-

Citation:

Dyshlyuk, N.V. (2017). Structure's features of esophagus and it's limphoid tissue of house sparrow. Scientific Messenger LNUVMB, 19(78), 26-29. 
зистой основы. Эпителиальный слой представлен многослойным плоским слабо ороговеваюшим эпителием и лучше развит в краниальной части этого органа. Вблизи железистой части желудка он переходит в простой ичилиндрический. В собственной пластинке слизистой оболочки выявляются пакеты многочисленных пишеводных желез, в которых регистрируется слизь. Их выводные протоки открываются на поверхность эпителия слизистой оболочки. Мылечная пластинка местами прерывистая, образована гладкой мышечной тканью. Подслизистая основа выражена слабо, сформирована, как и собственная пластинка, рыхлой волокнистой соединительной тканью и кровеносными сосудами.

В слизистой оболочке краниальной и каудальной частей пищевода между железами, их выводными протоками и в подслизистой основе на границе с мышечной оболочкой выявляются отдельные скопления диффузной лимфоидной ткани, которые представлены клетками лимфоидного ряда без заметных разрежений и уплотнений. Основу диффузной лимфоидной ткани образует ретикулярная ткань, волокна которой расположень плотно, не имеют определенной ориентации и формируют мелкоячеистую сеть. Пищеводная мигдалина, расположенная в слизистой оболочке участка перехода пищевода в железистую часть желудка, морфофункционально не зрелая. Она образована только локальньми незначительньми скоплениями диффузной лимфоидной ткани. Предузелки и лимфоидные узелки отсутствуют.

Мышечная оболочка пищевода образована гладкой мышечной тканью, которая формирует внутренний - циркулярный и наружный - продольный слои. Между ними-прослойки рыхлой волокнистой соединительной ткани и кровеносные сосуды.

Адвентициальная и серозная оболочки образованы рыхлой волокнистой соединительной тканью, а серозная - еще и покрыта мезотелием.

Ключевые слова: воробей домовый, пищевод, пищеводные железы, диффузная лимфоидная ткань, слизистая оболочка, мыциечная оболочка, адвентициальная (серозная) оболочка.

\title{
Structure's features of esophagus and it's limphoid tissue of house sparrow
}

\author{
N.V. Dyshlyuk \\ dushlyuk@ukr.net
}

\begin{abstract}
National University of Life and Environmental Sciences of Ukraine, Heroyiv Oborony Str., 15, Kyiv, 03041, Ukraine
\end{abstract}

The features of the structure of the esophagus and its lymphoid tissue of the house sparrow (Passer domesticus) have been studied. It is shown that its wall is formed by well expressed mucous, muscular and least developed adventitial (serous in the caudal part) shells. The mucosa forms 7-9 longitudinal folds of leaf-shaped and finger-shaped forms directed into the lumen of the esophagus. It consists of epithelium, lamina propria, lamina muscularis and submucosa. The epithelial layer is represented by a multi-layered flat, weakly keratinizing epithelium and is better developed in the cranial part of this organ. Near the proventriculus, it passes into a single-layered cylindrical. In its lamina propria of the mucosa there are bags of numerous large esophageal glands in which mucus is recorded. Their excretory ducts open onto the surface of the mucosal epithelium. The lamina muscularis is intermittent in places, formed by a smooth muscle tissue. The submucosa is weakly expressed and its own plate is formed by a loose fibrous connective tissue with blood vessels. Between the esophagus glands, their excretory ducts and in the submucosa of the tunica mucosa on the border with the tunica muscular are separate clusters of diffuse lymphoid tissue, which are represented by cells of the lymphoid series without noticeable rarefaction and densities. The basis of the diffuse lymphoid tissue is the reticular tissue, the fibers of which, are densely disposed and do not have a definite orientation and form a small grid.

In the area of transition of the esophagus to the proventriculus, the esophageal tonsil, which is inherent in many species of birds, is not expressed. In this area in the mucous membrane, only local accumulations of diffuse lymphoid tissue are recorded. There are no prenodules and lymphoid nodules. The tunica muscular of the esophagus is formed by a smooth muscle tissue, which forms the inner-circular and outer - longitudinal layers. Between them, layers of loose fibrous connective tissue and blood vessels are identified. Tunica adventitia (serosa) are formed by a loose fibrous connective tissue, and serosa is also covered by mesothelium.

Key words: house sparrow, esophagus, esophageal glands, diffuse lymphoid tissue, tunica mucosa, tunica muscularis, tunica adventitia (serosa).

\section{Вступ}

Згідно з сучасними даними, стравохід птахів є типовим трубкоподібним органом, який вирізняється високою еластичністю і розтяжністю. Він прямує від глотки до залозистої частини шлунка та має по довжині краніальну (шийну) і каудальну (грудо-черевну) частини (Krok, 1962). Мікроскопічно стінка стравоходу утворена слизовою, м'язовою і адвентиційною оболонками. В його каудальній частині зовнішньою є серозна оболонка. У товщі слизової оболонки містяться секреторні відділи і вивідні протоки стравохідних залоз, які продукують слиз. Біля них виявляються скупчення лімфоїдної тканини, що формують імунні (лімфоїдні) утворення, а в ділянці переходу стравоходу в залозисту частину шлунка - стравохідний мигдалик (Krok, 1962; Petushinova, 1985; Nagy et al., 2005).
Особливості будови стравоходу та його лімфоїдної тканини у дикої птиці вивчені ще недостатньо. Літературні джерела 3 цього питання поодинокі та неповнi, а щодо горобця домового відсутні (Kovtun et al., 2003; Harchenko et al., 2006).

Метою нашої роботи було дослідити особливості будови стінки стравоходу та його лімфоїдної тканини горобця домового.

\section{Матеріал і методи досліджень}

Матеріал для досліджень відібрали від статевозрілих горобців домових (Passer domesticus) (n=3). При виконанні роботи використовували загальноприйняті класичні методи мікроскопічних досліджень (Horalskyi et al., 2005). У процесі їх проведення шматочки стравоходу фіксували у 5-10\% водному розчині 
нейтрального формаліну. Матеріал ущільнювали шляхом заливки в парафін. Зрізи завтовшки 7-10 мкм фарбували гематоксиліном і еозином, за ван Гізон та імпрегнували азотнокислим сріблом за Келеменом (Kelemen, 1971).

\section{Результати та їх обговорення}

Проведеними дослідженнями показано, що стінка стравоходу горобця домового утворена добре вираженими слизовою, м'язовою і найменш розвиненою адвентиційною (серозною) оболонками.

Слизова оболонка формує поздовжні складки листоподібної і пальцеподібної форми (від 7 до 9), які частково закривають просвіт стравоходу. Вона складається 3 епітелію, власної та м'язової пластинок і підслизової основи. Епітеліальний шар представлений багатошаровим плоским слабо зроговілим епітелієм і краще розвинений в краніальній частині органу. Поблизу залозистої частини шлунка він переходить в простий циліндричний. Власна пластинка слизової оболонки добре розвинена. Вона утворена пухкою волокнистою сполучною тканиною 3 колагеновими, еластичними волокнами, містить дрібні кровоносні судини і секреторні відділи чисельних стравохідних залоз, в яких виявляється слиз. Вивідні протоки залоз відкриваються на поверхню епітелію слизової оболонки. М'язова пластинка утворена гладкою м'язовою тканиною, пучки клітин якої мають поздовжній напрямок. Місцями вона переривчаста. Підслизова основа слабо виражена. Вона утворена пухкою волокнистою сполучною тканиною 3 колагеновими, еластичними волокнами і дрібними кровоносними судинами.

У слизовій оболонці краніальної і каудальної частин стравоходу виявляються поодинокі скупчення дифузної лімфоїдної тканини, які представлені клітинами лімфоїдного ряду без помітних розріджень та ущільнень (рис. 1). Вони реєструються між стравохідними залозами, їх вивідними протоками і в підслизовій основі на межі з м’язовою оболонкою.

Основу дифузної лімфоїдної тканини утворює ретикулярна тканина, волокна якої розташовані щільно, не мають певної орієнтації і формують дрібнокоміркову сітку.

В ділянці переходу стравоходу в залозисту частину шлунка стравохідний мигдалик морфофункціонально незрілий (рис. 2, 3). В слизовій оболонці цієї ділянки виявляються лише локальні скупчення дифузної лімфоїдної тканини. Передвузлики і лімфоїдні вузлики відсутні.

М'язова оболонка стравоходу добре розвинена i представлена гладкою м'язовою тканиною, пучки клітин якої формують два шари: внутрішній циркулярний i зовнішній - поздовжній. Між шарами м'язової оболонки виявляються прошарки пухкої волокнистої сполучної тканини і кровоносні судини.

Адвентиційна і серозна оболонки утворені пухкою волокнистою сполучною тканиною, а серозна - ще й вкрита мезотелієм.

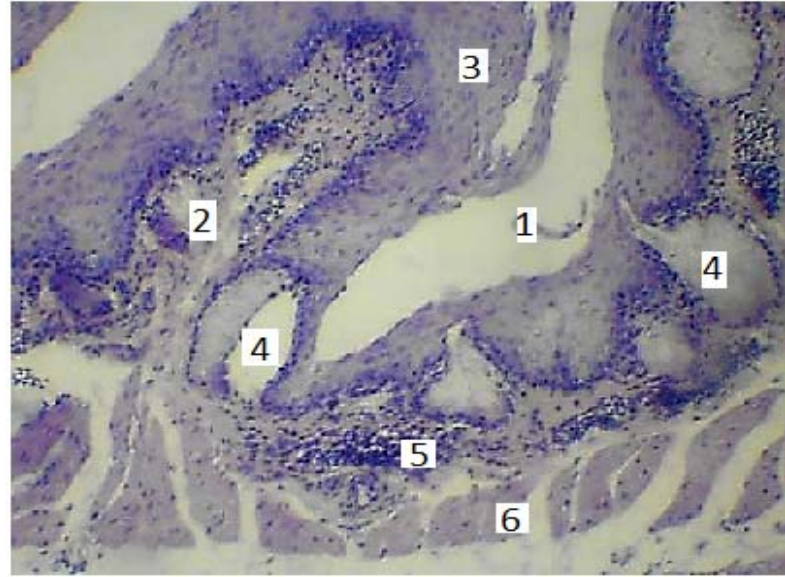

Рис. 1. Краніальна частина стравоходу горобця домового. Гістопрепарат

Фарбування гематоксиліном і еозином, х 90. 1 - просвіт стравоходу; 2 - складка слизової оболонки; 3 - епітелій; 4 стравохідні залози; 5 - дифузна лімфоїдна тканина; 6 м'язова оболонка

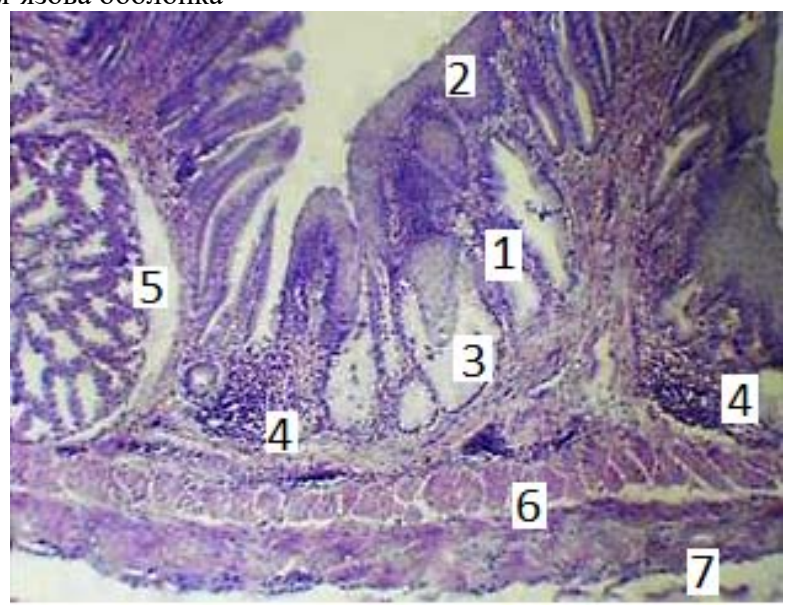

Рис. 2. Ділянка переходу стравоходу в залозисту частину шлунка горобця домового

Гістопрепарат. Фарбування гематоксиліном і еозином, $\times 63$ : 1 - слизова оболонка; 2 - епітелій; 3 - стравохідні залози; 4 - дифузна лімфоїдна тканина; 5 - часточка глибокої залози залозистої частини шлунка; 6 - м'язова оболонка; 7 - серозна оболонка

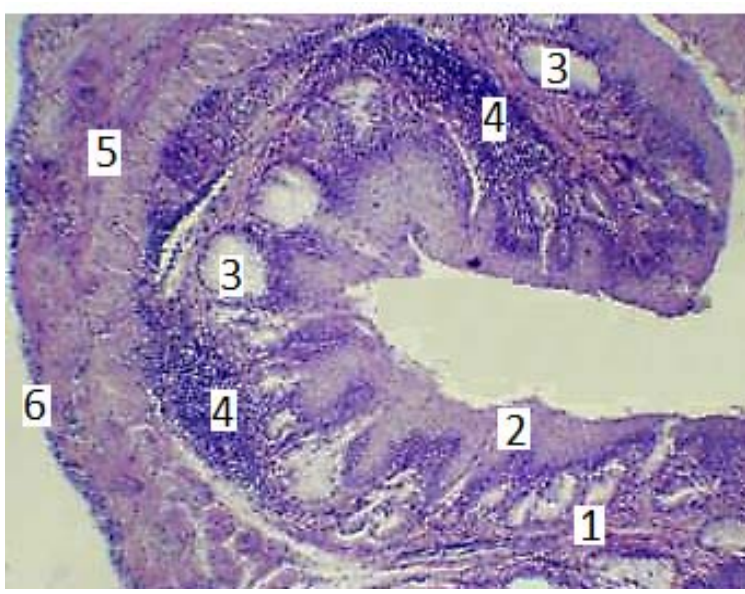

Рис. 3. Ділянка переходу стравоходу в залозисту частину шлунка горобця домового: Гістопрепарат. Фарбування гематоксиліном і еозином, ×63: 1 - складки слизової оболонки; 2 - епітелій; 3 -стравохідні залози; 4 дифузна лімфоїдна тканина; 5 - м'язова оболонка; 6 - серозна оболонка 


\section{Висновки}

Стінка стравоходу горобця домового утворена добре вираженими слизовою, м'язовою і найменш розвиненою адвентиційною (серозною в каудальній частині) оболонками.

В слизовій оболонці краніальної і каудальної частин стравоходу між залозами, їх вивідними протоками і в підслизовій основі на межі з м'язовою оболонкою виявляються поодинокі скупчення дифузної лімфоїдної тканини, які представлені клітинами лімфоїдного ряду без помітних розріджень і ущільнень.

Стравохідний мигдалик, який розташований в слизовій оболонці ділянки переходу стравоходу в залозисту частину шлунка, морфофункціонально незрілий. Він утворений лише локальними незначними скупченнями дифузної лімфоїдної тканини. Передвузлики і лімфоїдні вузлики відсутні.

Перспективи подальших досліджень. В подальшому планується вивчити особливості будови шлунка горобця домового та його лімфоїдної тканини.

\section{Бібліографічні посилання}

Krok, G.S. (1962). Mikroskopicheskoe stroenie organov sel'skohozjajstvennyh ptic s osnovami jembriologii. K.: Izd-vo Ukr. akademii s.-h. nauk (in Russian).

Petushinova, N.V. (1985). Vozrastnye izmenenija gistostruktury pishhevodnoj mindaliny kur pri selekcii krossa «Brojler-6». Intensifikacija pticevodstva.
Trudy Har'kovskogo s.-h. in-ta im. V.V. Dokuchaeva. Har'kov. 136, 80-84 (in Russian).

Nagy, N., Igyarto, B., Magyar, A. (2005). Oesophageal tonsil of the chicken. Acta Veterinaria Hungarica. 53(2), 173-188.

Harchenko, L.P., Zhigalova, E.E., Byrka, V.S., Kushh, N.N. (2006). Morfologicheskie osobennosti limfoidnyh obrazovanij slizistoj obolochki pishhevoda i zhelezistogo zheludka u nekotoryh vidov dikih ptic. Aktual'nye voprosy jevoljucionnoj, vozrastnoj i jekologicheskoj morfologii Belgorod, 177 (in Russian).

Kovtun, M.F., Harchenko, L.P., Birka, V.S. (2003). Limfoidnye obrazovanija kishechnoj trubki ptic i ih zashhitnaja funkcija. Aktualni pytannia farmatsevtychnoi ta medychnoi nauky ta praktyky. Zaporizhzhia: Vyd-vo ZDMU. 11, 75-81 (in Russian).

Horalskyi, L.P., Khomych, V.T., Kononskyi, O.I. (2005). Osnovy histolohichnoi tekhniky i morfofunktsionalni metody doslidzhen $u$ normi ta pry patolohii. Navchalnyi posibnyk. Zhytomyr: Polissia (in Ukrainian).

Kelemen, I. (1971). Novyj vidoizmenjonnyj metod impregnacii retikulinovyh volokon. Rumynskoe medicinskoe obozrenie, 18-23 (in Russian).

Received 4.09.2017

Received in revised form 27.09.2017

Accepted 2.10.2017 